\title{
Model Creation of Musical String Instrument Based on Ethnic Diversity in North Sumatera
}

\author{
Panji Suroso $^{1}$, Muklis Hasbullah ${ }^{1}$, Uyuni Widiastuti ${ }^{1}$, Herna Hirza ${ }^{1}$, \\ Pita H.D Silitonga ${ }^{1}$, Bakhrul Khair Amal ${ }^{2}$ \\ ${ }^{1}$ Lecturer at Faculty of Languages and Arts, State University of Medan \\ ${ }^{2}$ Lecturer in Social Science Faculty (FIS), State University of Medan. \\ b4khrul.4m4l@gmail.com
}

\begin{abstract}
This research is based on the curiosity about the phenomenon of the diversity of concepts and organizational structures of traditional stringed instruments in North Sumatra to be developed in finding new, more innovative concepts in creating North Sumatra local whisdom-based stringed musical instruments. The results of this study are expected to provide excellent benefits in research and development of science for lecturers, students and the wider community. The method used in this study is a qualitative approach and exploration besides art. The process of finding data and information is carried out thoroughly for overall and complete information about the diversity of traditional stringed musical instruments in North Sumatra. Data collected from two sources, namely primary data and secondary data. Primary data is obtained from the techniques of in-depth interviews (in-depth interviews) and joint observation (participant observation) which aims to explore data focused on focus groups (focus group discussions). The selection of informants is carried out on grouping key informants consisting of makers, users, experts and academics of traditional music. Secondary or primary data then organized for later exploration in creating musical instruments concocted with the diversity of local whisdom in North Sumatra. The results of this study are: Taking into account the various forms of musical instruments and the areas of the tones of each related instrument, then formulated to emit the tone by adopting and exploring existing instruments.
\end{abstract}

Keywords: creation; string music; ethnic diversity

\section{Introduction}

This research is oriented to the development of the creation of musical instruments in producing new concepts based on local whisdom in North Sumatra. This research is also based on the curiosity about the phenomenon of the diversity of concepts and organological structures of some traditional stringed musical instruments, such as those owned by Pakpak ethnicity, Karo ethnicity, Toba Batak ethnicity and ethnic Malays in North Sumatra and are now being eliminated by instrument products other stringed music from various parts of the country.

Based on literature studies on several previous studies such as: 1) research on Batoan L Sitepu (2013) on organological studies of Pakpak, 2) research on Beri Pana S (2013) on Organology Studies Kulcapi Karo, 3) Jakri Octora T (2014) on organology studies Gambus Melayu, 4) Gideon Simaremare (2015) research on organological studies of Toba Batak hasapi. The results of the study show data on the diversity of organological structures in the form of instruments, game techniques, and the relevance of the functionalities of each instrument which has very diverse characteristics.

Furthermore, based on the resume of the KDBK research team from the results of previous research, there are important issues to be addressed immediately. These issues include: 1) the patterns of making stringed music are mostly still carried out in very 
traditional ways and have not been touched by current industrial technology. 2) Its functionality is still very limited. 3) Less developed and less interested in the traditional musical instruments by the respective community groups and the wider community. 4) Musical instruments of this tradition are still unable to compete with stringed musical instruments from other countries.

In addition, based on the FGD which was conducted by a team of lecturers with traditional music artists, music academics and students about the existence of traditional stringed musical instruments in North Sumatra, several important issues were found to be overcome. These problems include the fact that there is an attitude of ignorance between traditional artists and music academics in North Sumatra to develop the diversity of traditional musical instruments to be able to compete with other popular and popular musical instrument products in almost all parts of the country. Based on the temporary findings in the field, that at present almost most music artists and the general public in North Sumatra are more fond of using modern stringed music products imported from abroad. If conditions like this are allowed to drag on, then in the end the traditional stringed musical instruments possessed by North Sumatra become extinct and even become extinct, replaced by other stringed instruments which do not breathe ethnic culture in the archipelago that deserves to be preserved and preserved as a wealth from Maha Karya - Maha by ethnic ancestors in North Sumatera.

Based on the initial resume of the results of previous studies and the results of the lecturer team discussions with various parties, it can be identified the things that need to be followed up to be corrected immediately, namely: 1. It is important to study the concept of organology in the diversity of traditional string music in North Sumatra to be explored more deeply as knowledge to be developed in creating musical instrument products that are more innovative and more flexible, both in form and function. This effort is also specifically intended to be able to develop and discover new concepts in the field of music creation based on local whisdom in North Sumatra in the interests of continuing ethnic music learning and for the benefit of the wider community.

\section{Methodology}

The approach uses in this study is a qualitative approach. The process of tracking data and information is done diachronically to find out in a complete and complete manner the diversity of traditional stringed musical instruments in North Sumatra. Data collected comes from two sources, namely primary data and secondary data. Primary data is obtained through in-depth interview techniques and participant observation aimed at collecting data followed by focus group discussions.

Other features are video cameras, photos and audio visual recorders that are very useful in documenting data. The selection of informants is based on grouping key informants that include artists making, users, experts and academics of basic music. The number of informants is not limited as long as the data needed is still needed to answer the objectives of this study. Secondary data is obtained from relevant agencies and related organizations, such as documents about the existence of traditional stringed instruments and so on.

The stages and steps to be carried out in this study are: 
1) Research preparation phase which includes designing proposals, conducting literature studies, determining research topics, formulating problems and research objectives, determining the location of research, and establishing research methods.

2) Phase of collecting primary data and secondary data. Primary data is obtained through indepth interviews (participant interviews) and participant observation aimed at collecting data followed by focus group discussions. Secondary data is obtained from relevant agencies and related organizations, such as documents about the existence of traditional stringed instruments and so on.

3) The phase of data analysis is done by categorizing and analyzing primary and secondary data, conducting discussions with experts. Next formulate the concepts and models for the creation of ethnic diversity based instruments of North Sumatra.

4). The trial phase applies the formulation of concepts and models for the creation of ethnic diversity based instruments of North Sumatra. The trial process is done by preparing the needs of materials and equipment. Applying the formulation of concepts and models in the creation of stringed musical instruments. Then make corrections and improvements to the problems that occur. Next set the concepts and models for the creation of ethnic diversitybased stringed music in North Sumatra.

5) The production phase of the creation of North Sumatra ethnic diversity picking musical instruments is by preparing equipment needs, selecting quality raw materials and making the process of making stringed musical instrument products based on the concepts and models of the results of studies that have been carried out.

6) The stage of concluding the results and making a report on the research findings. At this stage the results of the research will be concluded, conducting a seminar on the results and making a report on the results of the study.

The following is a research flowchart thinking (Fishbon diagram)

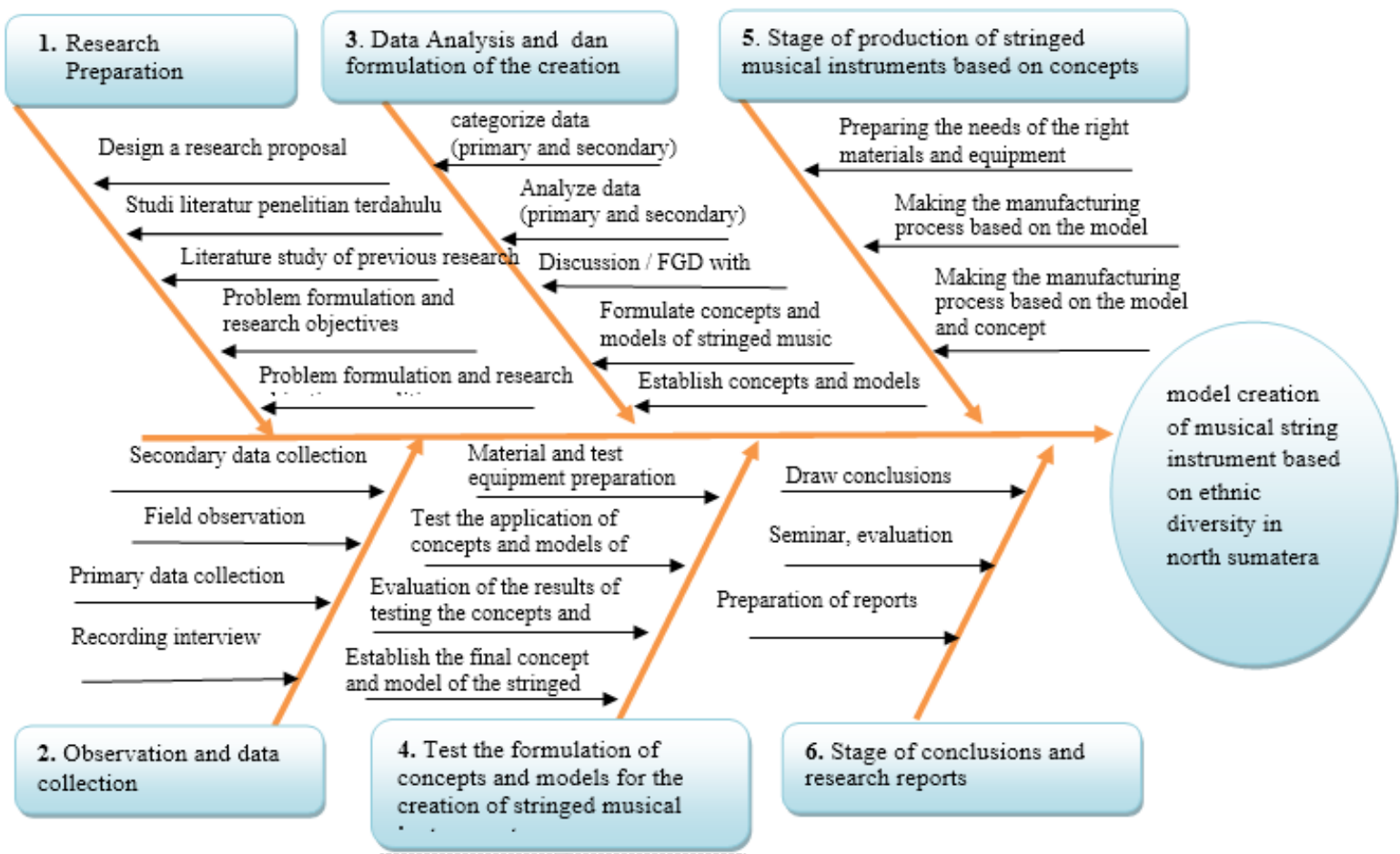




\section{Result and Discussion}

\subsection{Concentration Analysis of North Sumatra Stringed Instrument Music Organology (Kulcapi, Hasapi, Kucapi and Gambus)}

In this case, a review of the organology of each of the traditional stringed musical instruments in North Sumatra such as kulcapi (karo tradition), Hasapi (tradition of batak toba), khucapi (Pak-pak tradition), Gambus (Malay tradition) is discussed. From each organology concept contained in the stringed musical instruments of the tradition, it will then be analyzed and explored as a reference in finding new models of the creation of ethnic diversity based music from North Sumatra. The following is a review of some of the organological concepts of Petik musical instruments found in North Sumatra.

\section{a. Overview of Structure of Instrument Organology in Kulcapi Karo}

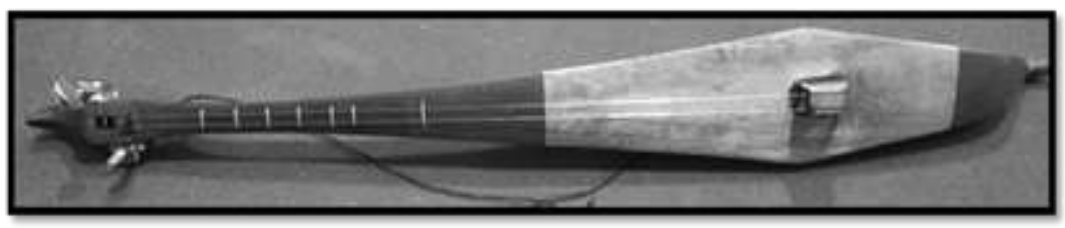

Structure concept of kulcapi was classified into a long-necked and two-stringed lute instrument. The structure of the parts of the kulcapi consists of: 1) head of kulcapi, 2) neck of kulcapi (neck), 3) body or stomach of kulcapi as resonator, 4) hole of resonator. 5) part of tail

- The head

The head of kulcapi is designed as an animal head shaped ornament with a size of 9 $\mathrm{cm}$ to $9.5 \mathrm{~cm}$. The head is equipped with tuning on the right side and left side of the head of the head as a place to connect the two strings or strings made of metal.

- Kulcapi neck section

The neck of the head is $52 \mathrm{~cm}$ long and the neck width near the head is $2 \mathrm{~cm}$ in size and the neck size of the kulcapi widens on the part adjacent to the stomach of the kulcapi following its shape which is approximately $3 \mathrm{~cm}$ in size.

In the neck there are sections as a space divider for the position of each position with each pret distance starting from the near part of the head; first pret $4.5 \mathrm{~cm}$, second pret $2.2 \mathrm{~cm}$, third pret $2.5 \mathrm{~cm}$, fourth pret $2.25 \mathrm{~cm}$ pret to five, $2.4 \mathrm{~cm}$. One string distance with another $1 \mathrm{~cm}$

- The front of the body is smooth

The front of kulcapi is the resonator cover found in t kulcapi body as a vibrating chamber which greatly influences the production of kulcapi sound. The width of the section near the tail is approximately $5 \mathrm{~cm}$, the width of the center of the head is $9 \mathrm{~cm}$ and the width of the section near the neck is $4 \mathrm{~cm}$.

- Resonator hole section

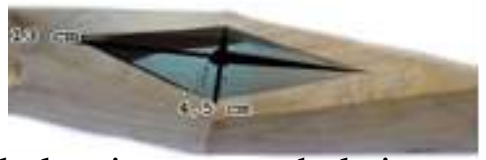

The kulcapi resonator hole is a rectangular trapezoidal shape and is located at the back of kulcapi body. The resonator hole is $13 \mathrm{~cm}$ long and 4.5 inches wide. 
- The tail section

The head tail has a length of $6 \mathrm{~cm}$ in width, adjusted to the body of the head and shaped tapered to the end.

- The distance between the strings is right

Kulcapi has two strings mounted from the head to the end of the body, the width of the distance between the two strings is $1 \mathrm{~cm}$.

- Good scale

Kulcapi scales are pentatonic scales.

\section{b. Overview of Hasapi Batak Toba Organological Structures}

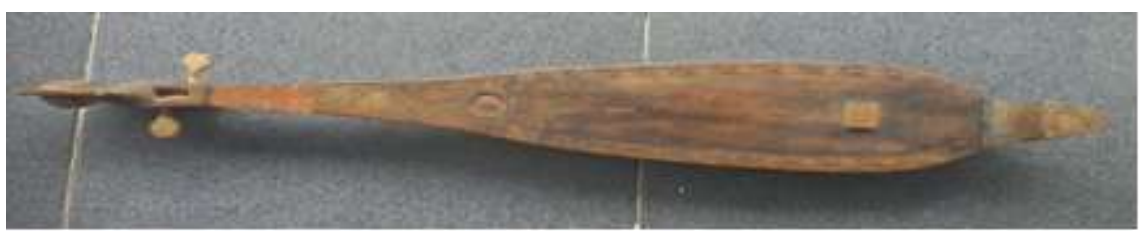

Structure concept of the kulcapi is classified into a long-necked and stringed lute instrument 2. The structure of parts - hasapi consists of: 1) hasapi head, 2) hasapi neck (neck), 3) hasapi body or abdomen as resonator, 4) resonator hole

The head part of Khucapi is a statue ornament with a floor width of $5 \mathrm{~cm}$ and a height: $15 \mathrm{~cm}$ and is equipped with a tuning khucapi measuring $5 \mathrm{~cm}$ wide, $5 \mathrm{~cm}$ long, $6 \mathrm{~cm}$ high as a place to hook strings or strings.

\section{- Hasapi neck section}

On the neck of Hasapi in the form of a long neck, there is no barrier, some even have a mirror layer on the front, the size of the neck length is $32 \mathrm{~cm}$.

- The front of the Hasapi body

The front of the Hasapi body has a resonator cover.

on the resonator cover there is one container for connecting the strings.

The length of the resonator cover: $20 \mathrm{~cm}$, width: $9 \mathrm{~cm}$, the size of the length of the string container: $3.4 \mathrm{~cm}$, width: $3 \mathrm{~cm}$, height: $2 \mathrm{~cm}$.

- Resonator hole section

The resonator hole is located on the back of the hasapi body, a rectangular trapezoidal shape. Size Hole length: $13 \mathrm{~cm}$, hole width: $4.1 \mathrm{~cm}$.

\section{- Tail section}

On the tail there are motives of Toba Batba carvings, the size of the tail length: $10 \mathrm{~cm}$, width: $3 \mathrm{~cm}$.

\section{- String distance}

Hasapi has two strings of string mounted longitudinally from the head to the end of the hasapi body. The distance between the two strings is $1 \mathrm{~cm}$.

- Hasapi scales

The area of the khucapi tone is pentatonic.

\section{c. Prior to Organology Structure of the Instrument in Pakpak Barat}

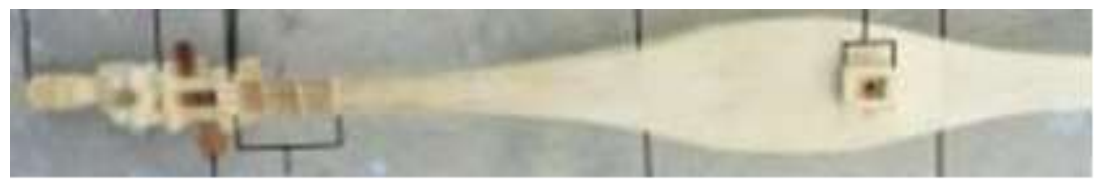


Structure concept of kulcapi is classified into a long-necked and two-stringed lute instrument. The structure of the parts of the kulcapi consists of: 1) head of kulcapi, 2) neck of kulcapi (neck), 3) body or stomach of kulcapi as resonator, 4) hole of resonator. 5) part of tail

\section{- Khucapi head section}

The head part of Khucapi is a statue ornament with a floor width of $5 \mathrm{~cm}$ and a height: $15 \mathrm{~cm}$ and is equipped with a tuning khucapi measuring $5 \mathrm{~cm}$ wide, $5 \mathrm{~cm}$ long, $6 \mathrm{~cm}$ high as a place to hook strings or strings.

\section{- Khucapi neck section}

The neck there is a barrier (kruis-kruis), the size of the neck length is $32 \mathrm{~cm}$, the length of the cruising section I: $3 \mathrm{~cm}$, the length of the section cruising II: $3 \mathrm{~cm}$, the length of the section cruising III: $3 \mathrm{~cm}$.

- The front of the body khucapi

The front of the khucapi body is a resonator cover of Khucapi. on the resonator cover there is one container for connecting the strings. The length of the resonator cover: 20 $\mathrm{cm}$, width: $9.5 \mathrm{~cm}$, the size of the length of the string container: $3.4 \mathrm{~cm}$, width: $3 \mathrm{~cm}$, height: $2 \mathrm{~cm}$.

- Resonator hole Section

The resonator hole is located at the back of the body, shaped like a rectangular trapezoid. Size Hole length: $13 \mathrm{~cm}$, hole width: $4.1 \mathrm{~cm}$.

- Tail section

On the tail is a monkey head carved, the size of the tail length: $18 \mathrm{~cm}$, width: $3 \mathrm{~cm}$.

- String distance

Khucapi has two strings of string which are stretched from the beginning of the head of the khucapi to the ends of the body of the head. The distance between the two strings is $1 \mathrm{~cm}$.

- Khucapi scales

The tone area of khucapi is pentatonic (Bes-C-E-F-A-Bes)

\section{d. Overview of the Structure of Malay Gambus Organology}

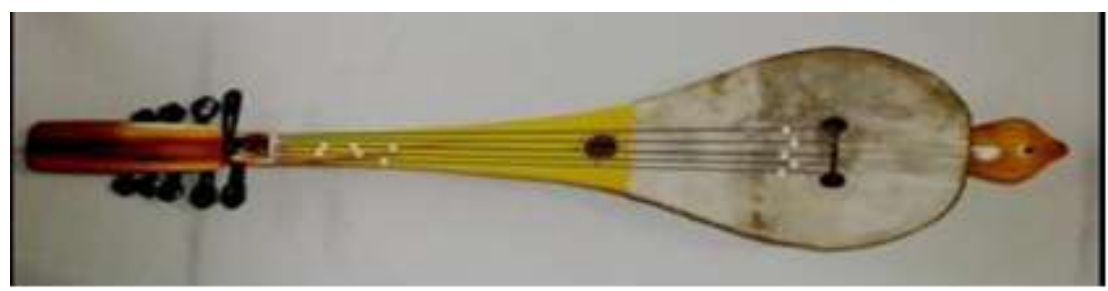

Structure concept of gambus shape is classified into a long-necked and nine-stringed lute instrument. The structure of parts - gambus parts consist of: 1) head of the head, 2) neck of kulcapi (neck), 3) body or abdomen of kulcapi as resonator, 4) hole of resonator .5) part of tail.

\section{- Head Section}

The head has a length of $26 \mathrm{~cm}$, at the head cover has a length of $21 \mathrm{~cm}$, width of 7.5 $\mathrm{cm}$ and a thickness of $1 \mathrm{~cm}$. For the head (seen from the side) the height has different variations as shown in the following picture. 
- Neck section

In the neck there is a finger board like the guitar parts, except that the difference between the fingers of the gambus board is that there is no fret which is the distance of the tone and there is a sound hole on the finger board. For the size of the finger board on the surface and the thickness of the top to bottom has a different size as seen in the picture.

- Lute body parts

The body of the gambus has a length of $29 \mathrm{~cm}$ and a width of $25 \mathrm{~cm}$ which is covered by goat skin and abdominal height from the bottom up or from the back to the front 15

$\mathrm{cm}$. In the middle there is a string support (cedak) which serves as a support for the lower strings.

\section{- Tail section}

The tail is the lowest part found in this gambus. On the tail he shaped it like the shape of a dome of a house of worship (mosque). The tail size is $9 \mathrm{~cm}$ long, $8 \mathrm{~cm}$ wide and 2 cm thick.

\section{- Distance of strings}

The strings have different distances in the arrangement. There are 5 lines of string. For the upper part the strings have a distance of $1 \mathrm{~cm}$ each, and for 4-layered strings it has a distance of $0.3 \mathrm{~cm}$. For the lower part of the strings the distance of the strings is $1,5 \mathrm{~cm}$ each, and for 4 strings the strings have a distance of $0.3 \mathrm{~cm}$. In the cedak / horses section it has a length of $9 \mathrm{~cm}$ and a height of $2.8 \mathrm{~cm}$ as a regulator of the strings so as not to stick to the goat's skin.

Comparative Analysis Table of Struketur Organology Picking Instruments (kulcapi, hasapi, khucapi, gambus)

\begin{tabular}{|l|l|l|l|}
\hline No & $\begin{array}{l}\text { Comparison } \\
\text { of instru- } \\
\text { ment types }\end{array}$ & $\begin{array}{l}\text { The findings of analysis } \\
\text { of trends in the similarity } \\
\text { of the concepts of } \\
\text { organological structures }\end{array}$ & $\begin{array}{l}\text { Analysis findings } \\
\text { the tendency of differences in the } \\
\text { concept of organological structures }\end{array}$ \\
\hline $\begin{array}{l}\text { Kulcapi } \\
\text { Kasapi } \\
\text { Gambus }\end{array}$ & $\begin{array}{l}\text { Head section } \\
\text { The head part of the } \\
\text { kulcapi instrument, hasapi, } \\
\text { khucapi tends to have a } \\
\text { characteristic of length and } \\
\text { width, besides that in each } \\
\text { part of the head both have } \\
\text { two ears as tuning tone } \\
\text { tuners as tone tuners. }\end{array}$ & $\begin{array}{l}\text { Head Section } \\
\text { There is a slight difference in the form } \\
\text { of ornament of each culture, hasapi, } \\
\text { khucapi and gambus as the } \\
\text { characteristics of each ethnic group. } \\
\text { In gambus instruments there are } \\
\text { fundamental differences from the } \\
\text { existence of ears or tuning setemer } \\
\text { which amount to nine pieces that are } \\
\text { very different from kulcapi, hasapi and } \\
\text { khucapi }\end{array}$ \\
& $\begin{array}{l}\text { Neck section } \\
\text { in kulcapi, hasapi, khucapi } \\
\text { instruments tend to be } \\
\text { similar in size to length }\end{array}$ & $\begin{array}{l}\text { The neck section of each instrument } \\
\text { (kulcapi, hasapi, khucapi and gambus } \\
\text { also has differences such as: }\end{array}$ \\
\hline
\end{tabular}




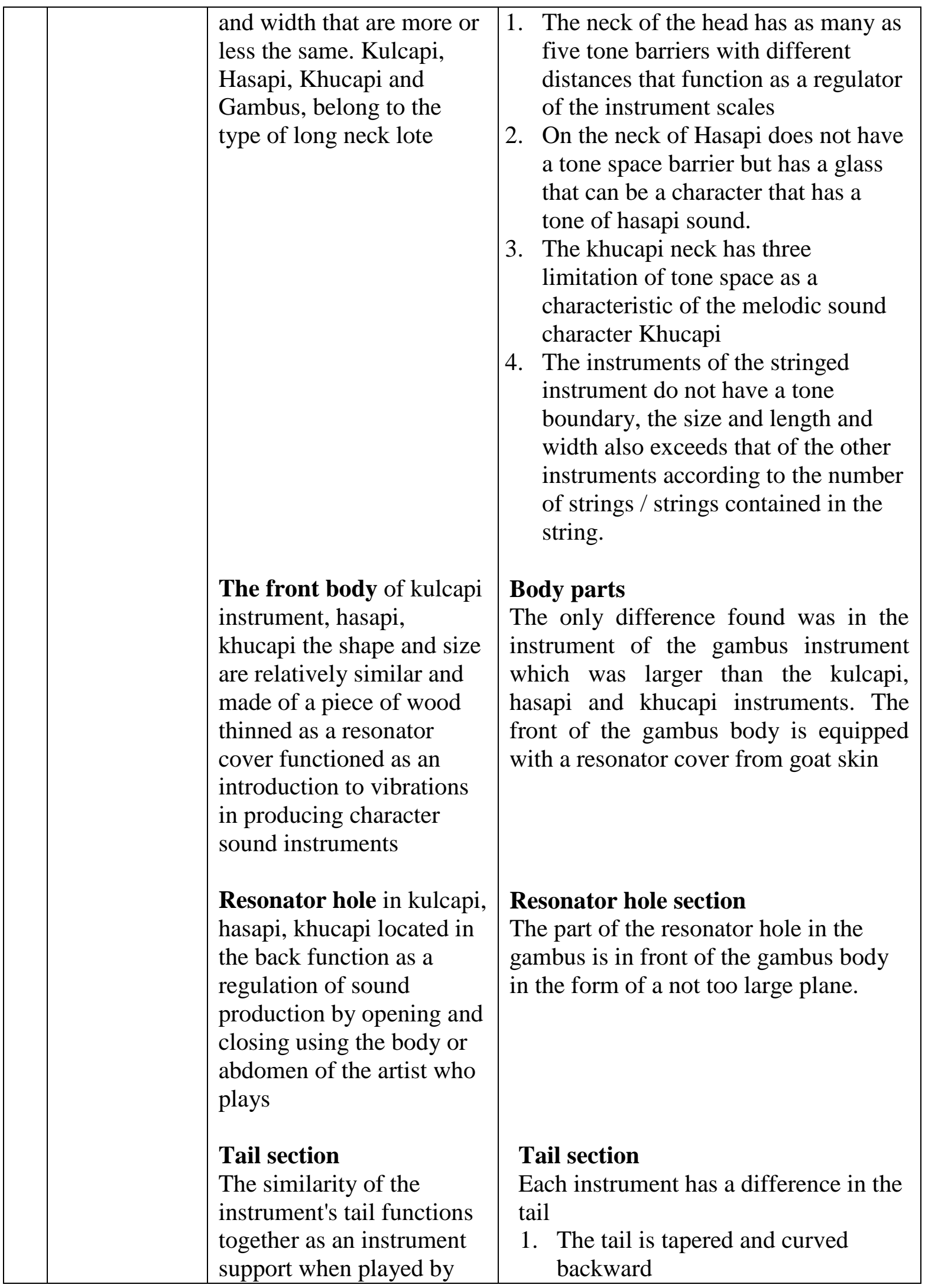




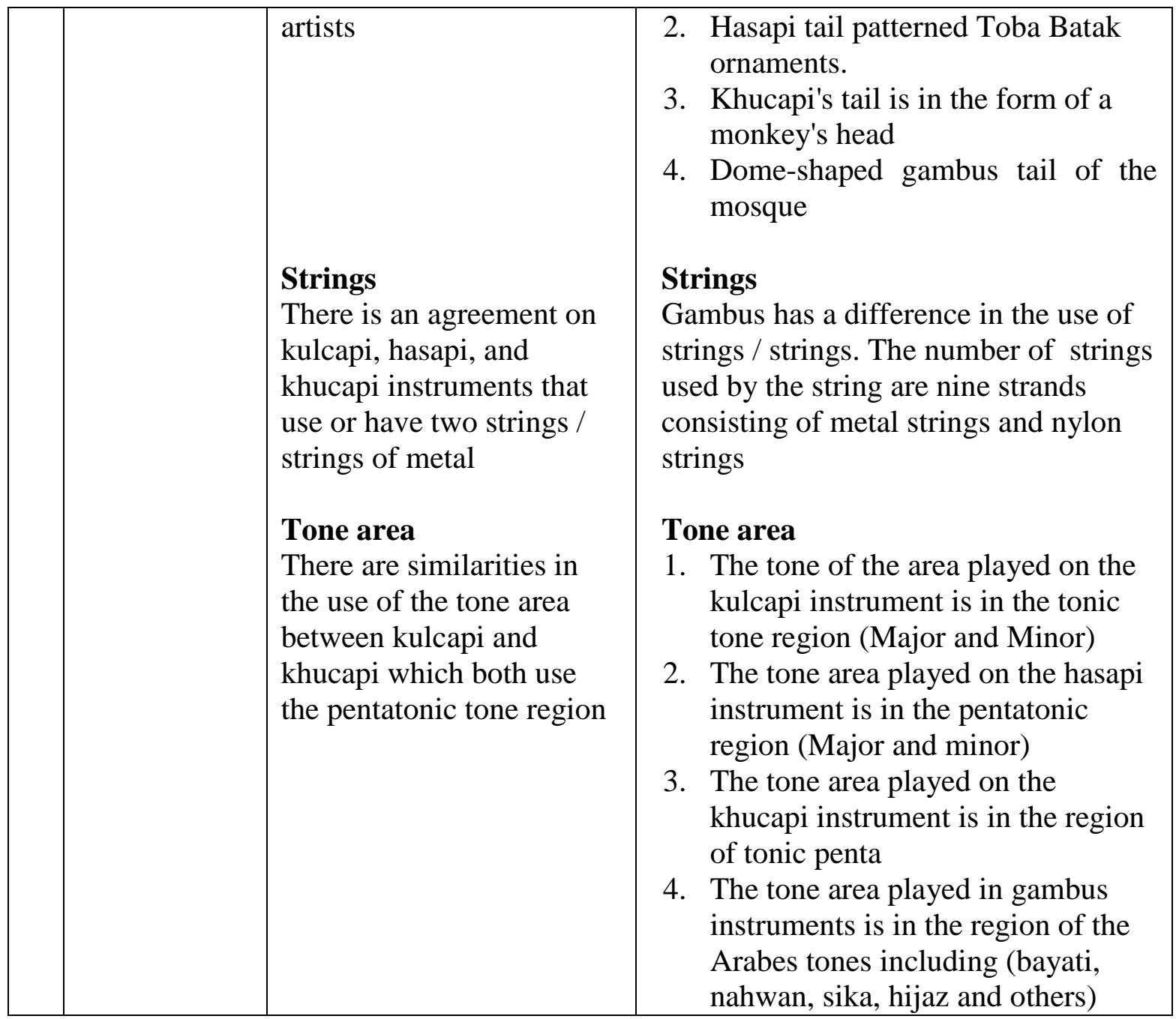

\subsection{Formulation of the Concept of Creation in the Form of Stringed Musical Instruments Based on Ethnic Diversity in North Sumatera}

Based on the results of the analysis of the similarities and differences of each of the traditional musical instrument consumptions, a North Sumatra ethnic diversity based instrument model can be formulated by adopting the method and collaborating elements of the equation and exploring existing differences into new concepts. By adopting, collaborating and exploring these elements with the aim of not eliminating the overall characteristics of each of these instruments, it was created the consequence of creating the stringed musical instrument model as follows.

1. Head section

By considering bringing back the diversity of patterns that each traditional instrument has, then adopting existing forms by collaborating and exploring elements of the head part in the kulcapi, hasapi and khucapi instruments becomes a new concept, namely by making the shape of the head of the instrument is round opal shaped and has 4 tuning stemers in an effort to present the diversity of characters and expand the tone area in one instrument.

2. Neck section 
In formulating of instrument's concept of neck part on the research team conducted exploration to unify the concept of each instrument, namely by presenting a number of existing concepts. For example, it presents five tone space barriers at the top of the neck and at the bottom empties the tone space barrier.

This effort to still be able to bring back the characteristics of each tradition. By continuing to collaborate the elements that exist then the neck of the instrument has increased the size of the width to be twice the width of the neck of the previous instrument to accommodate the 4 string consents in expanding the tone area both pentatonic and diatonic.

3. Instrument body parts

At the front, the same thing is done, which is still adopting the existing elements and exploring the addition of ornaments to beautify the shape of the front body. Taking into account the sound quality produced, the research team still uses the old concept, namely by presenting a resonator cover on the front of the instrument body. The closure of this resonator was explored by presenting cultural symbols from each ethnic group that were diadobsi, namely the symbol of ethnicity Karo, Malay, Toba Batok and Pakpak in certain parts.

4. Resonator hole

The resonator hole will be located on the back and still follow the old pattern and added three resonator holes that are not too large in the front as an attempt to expand the sound of the instrument.

5. Tail section

The tail section is functionally still an instrument part that can be supported on the player's arm. But aesthetically the tail must have the beauty of its shape. In this case the tail section is conceptualized in a form that is derived from the diversity of the motifs of the traditional artisan which are related in a form that has aesthetic value.

6. Strings / strings

In the draft concept of the North Sumatra ethnic diversity based stringed musical instrument using four strings / strings of metal and strings of synthetic nylon material. The reason for using four strings is to be able to expand the range of playing in the tone area and still be able to present melodic characters from each of the related ethnicities.

7. Tone area

By using the four strings / strings of the tone area it will clearly be wider covering the area of the related tradition, both diatonic tones and pentatonic tones. Each string will be $1 \mathrm{~cm}$ apart, the interval between strings 1 and 2 is tert, the distance between string 2 and string three is tert, the distance between strings 3 and 4 is kwin. This is adjusted to the interval interval arrangement in kulcapi (kwin string interval distance) accommodated on strings 4 and 5, khucapi (ters string interval interval) is accommodated on strings 3 and 2, and hasapi distance (tersar string interval) is accommodated on strings 2 and 1 Thus, playing the tone area will become wider and can be more participative in developing patterns of melodic forms. 


\section{Sketch of a form of stringed musical instruments based on ethnic diversity in North Sumatera}

\subsection{Instrument Making Process}

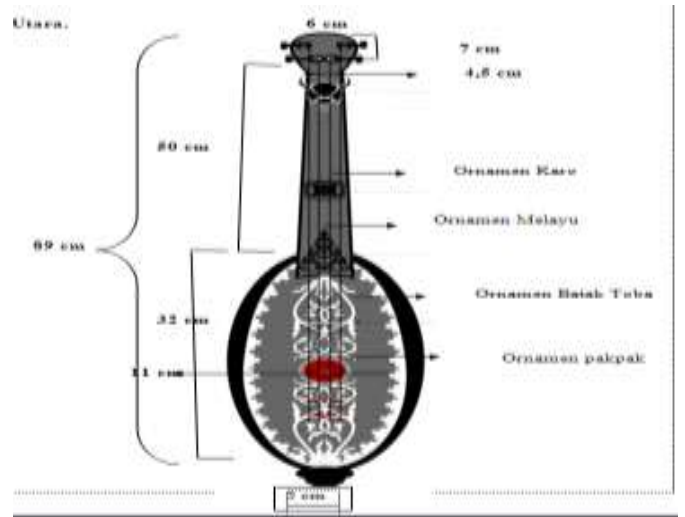

After reviewing, analyzing and formulating the conceptual form of the instrument the research team carried out several stages including:

- Preparing equipment and raw materials to be used on the basis of the formula for the creation of stringed musical instruments. The equipment used includes: measuring instruments (ruler), wood cutting machines, wood smoothers, wood holes, and some chisels to form wood. The raw material used is the type of mahogany or tualang wood, this type of wood has good quality in sound production and is easy to form according to the formulated consequences.

- After the equipment and raw materials are available, the process of making stringed musical instruments begins to be carried out step by step to produce the desired form according to the requirements. The steps are as follows:

1. Forming images on wooden blocks

2. The beam formation process becomes the basic form of the instrument

3. The perforation process in the resonator section

4. The process of making the front resonator cover

5 . The process of forming the head according to the motive.

6 . The process of forming the tail according to the motif

7. The process of smoothing all parts of the instrument

8. The process of mounting ears or tuning the stem in the head

9. The process of mounting the tone on the top of the instrument neck,

10. The second stage of refining process for certain parts

11. The process of installing strings / strings.

12. The process of testing and evaluating the sound of instruments

13. Revision process for incompatibility.

14. The process of giving traditional ornamental motifs to the instrument.

15. Finishing process.

\section{Conclusion}

Based on the findings of analysis, the formulation of instrument's form can be concluded in two ways: 
1. Formulate the structure instrument, namely:

- Taking into account the findings of similarities and differences of instrument-related organological concepts, the conceptual instrument form can be constructed by adopting and developing existing equations, and exploring differences into a single unit in the structure of new stringed musical instruments.

- In formulating the concept of instrument's form was associated with several traditional ornamental motifs (Karo, Melayu, Toba Batak and PakPak) to add to the aesthetic value of instrument.

2. Formulate the range of the instrument tone area, namely:

- Taking into account the tone area of the related traditional instrument which has differences, then an extension of the tone area is formulated by adopting all the differences to remain present in the new instrument. In this case four strings of string / string are used which can represent the entire tone area of the related instrument. The interval pattern of the tone is set on each string based on the distance pattern.

- Kulcapi Karo on strings 4 and 3, which is spaced kwin (pentatonic tone area)

- Khucapi Pakpak on strings 3 and 2 is a distance pattern ters (pentatonic tone area)

- Hasapi Toba on strings 2 and 1, namely the distance pattern (diatonic tone region)

- To present the Arabes scale pattern as the tone area of the Gambus instrument, it will be done by adjusting the interval interval of 1,2,3,4 based on the tone area in question.

\section{References}

Dian Octavia K, 2014. Struktur Organologi Hasapi dalam Gondang Hasapi Pada grup Musik Etnis Pardomuanta di Surabaya, Apron Jurnal Pemikiran seni Pertunjukan vol 1. No 5 http: // jurnalmahasiswa. unesa.ac.id/ index. php/ apron / article/view/8947/11962

Hornbostel, Erich M. Von and Curt Sach, 1961. Clasification of Musical Instrument. Translate from original German by Anthony Baines and Klausss P.Wachsmann.

I Made Winarta, Dr.Drs. dkk, 2016. Proses Pembuatan Gitar Ukir I Wayan Tuges Di Desa Guwang, Kecamatan Sukawati, Kabupaten Tingkat Ii Gianyar, Jurnal Pendidikan Seni Rupa Universitas Pedidikan Ganesha , Vol.5, no 2, https: // ejournal. undiksha. ac.id / index. php/JJPSP/ article/ view/ 8052

Merriam, Allan P, 1964. The Antropology of Music. North Western : University Press

Sihotang Batoan L, 2015. Kajian Organologi Kucapi PakPak Buatan Bapak Kami Capah di Kecamatan Kaerajaan Kabupaten PakPak Bharat. Skripsi Sarjana Departemen Etnomusikologi Fakultas Ilmu Budaya Universitas Sumatera Utara

Simaremare Gidon, 2015. Kajian Orgonologi Hasapi Batak Toba buatan Guntur Sitohang di Desa Turpuk Limbong Kecamatan Harian Boho Samosir, Skripsi Sarjana Departemen Etnomusikologi Fakultas Ilmu Budaya Universitas Sumatera Utara

Sitepu Beri Pana, 2013. Kajian Organologi Kulcapi Pada Masyarakat Karo Buatan Bapak Pauji Ginting Skripsi Sarjana Departemen Etnomusikologi Fakultas Ilmu Budaya Universitas Sumatera Utara.

Sunarto, B. 2013 Epistemologi Penciptaan Seni, Idea Press Jogjakarta.

Tobing Jackry Octora, 2014. Kajian Organologis Alat Musik Gambus Buatan Bapak Syahrial Felani, Skripsi Sarjana Departemen Etnomusikologi Fakultas Ilmu Budaya Universitas Sumatera Utara. 